\title{
Інтелектуальний потенціал міських громад як чинник підвищення їх конкурентоспроможності
}

\author{
К. О. Липовська
}

Дніпропетровський регіональний інститут державного управління Національної академї державного управління при Президентові Украӥни

УДК 332.14

DOI: 10.15421/15201751

Автор розглядає інтелектуальний потенціал міських громад - знань та компетентностей людей, які проживають у місті, їх інтелектуальної власності та організаційних можливостей і доводить, що інтелектуальний потенціал громади відіграє ключову роль в сучасному розвитку міста та його конкурентних переваг.

На думку автора, інтелектуальний потенціал створює нові конкурентні переваги малим і середнім містам, які отримують можливість стати рівноправними центрами економічної діяльності. Автор доводить, що важливою конкурентною перевагою міста мають стати кваліфіковані професійно підготовлені кадри місцевого самоврядування, що володіють сучасними знаннями й сучасними технологіями управління.

3 огляду на дві складові інтелектуального потенціалу міста, людську й організаційну, автор виділяє основні напрями діяльності органів місцевого самоврядування, адміністрації міста в сфері підтримки і розвитку його інтелектуального потенціалу: формування та підтримка людського потенціалу міста за допомогою підвищення знань і компетентності громади, підготовки необхідних фахівців; збереження наявного рівня й розвиток сучасних видів інформаційного та організаційного забезпечення всіх споживачів міста. У межах цих напрямів для малого і середнього міста найбільш актуальними стають: керована міграція кваліфікованих кадрів, пріоритетний розвиток освіти й професійного навчання, розвиток інформаційних технологій, захист інтелектуальної власності, створення професійного кадрового потенціалу органів місцевого самоврядування.

Ключові слова: інтелектуальний потенціал міської громади; місто; конкурентоспроможність; органи місцевого самоврядування

\section{The intellectual potential of urban communities as a factor in increasing their competitiveness \\ K. O. Lipovska \\ Dnipropetrovsk Regional Institute of Public Administration, National academy for public} administration under the President of Ukraine

The author examines the intellectual potential of urban communities - knowledge and competencies of people living in the city, its intellectual property and organizational capabilities, and proves that the intellectual potential of the community plays today the key role in the modern development of the city and in the development of its competitive advantages.

According to the author, the intellectual potential creates new competitive advantages for small and medium-sized cities, which have the opportunity to become equal centers of economic activities. The author proves that the important competitive advantage of the city has to become the qualified and professionally trained human resources of the local self-government, having the modern knowledge and modern management technologies.

Keeping in mind two components of the intellectual potential of the city - human and organizational

Цитування даної статті: Липовська К. О. Інтелектуальний потенціал міських громад як чинник підвищення їх конкурентоспроможності / К. О. Липовська // Аспекти публічного управління. - 2017. - Т. 5. - № 12. C. 59-66.

Citation of this article: Lipovska, K.O. (2017). The intellectual potential of urban communities as a factor in increasing their competitiveness [The intellectual potential of urban communities as a factor in increasing their competitiveness]. Public administration aspects, 5 (12), 59-66.

Received: 12.12 .2017

Accepted: 19.12.2017 
ones, the author highlights the main areas of activities of the local self-government bodies and administration of the city in the field of support and development of its intellectual potential: formation and support of the human potential of the city through raising the knowledge and competence of the community, training of required specialists; preservation of the existing level and development of modern types of informational and organizational supporting of all city consumers. Within the limits of these areas for small and medium-sized cities, the most relevant ones become the following: the managed migration of skilled human resources; the priority development of education and vocational training; the development of information technologies; the protection of the intellectual property; the creation of the professional human resource capacity of the local self-government bodies and administration of the city.

Keywords: intellectual potential of the urban community; city; competitiveness; local selfgovernment bodies

\section{Интеллектуальный потенциал городских общин как фактор повышения их конкурентоспособности \\ Е. А. Липовская}

Днепропетровский региональный институт государственного управления Наџиональной академии государственного управления при Президенте Украины

Автор рассматривает интеллектуальный потенциал городских общин - знаний и компетенций людей, проживающих в городе, их интеллектуальной собственности и организационных возможностей и доказывает, что интеллектуальный потенциал общины играет ключевую роль в современном развитии города и развития его конкурентных преимуществ.

По мнению автора, интеллектуальный потенциал создает новые конкурентные преимущества малым и средним городам, которые получают возможность стать равноправными центрами экономической деятельности. Автор доказывает, что важным конкурентным преимуществом города должны стать квалифицированные профессионально подготовленные кадры местного самоуправления, обладающие современными знаниями и современными технологиями управления.

Учитывая две составляющие интеллектуального потенциала города, человеческую и организационную, автор выделяет основные направления деятельности органов местного самоуправления, администрации города в сфере поддержки и развития его интеллектуального потенциала: формирование и поддержка человеческого потенциала города посредством повышения знаний и компетентности общины, подготовки необходимых специалистов; сохранение имеющегося уровня и развитие современных видов информационного и организационного обеспечения всех потребителей города. В рамках этих направлений для малого и среднего города наиболее актуальными становятся: управляемая миграция квалифицированных кадров, приоритетное развитие образования и профессионального обучения, развитие информационных технологий, защита интеллектуальной собственности, создание профессионального кадрового потенциала органов местного самоуправления.

Ключевые слова: интеллектуальный потенциал городской общины; город; конкурентоспособность; органы местного самоуправления

Постановка проблеми. В сучасних умовах, коли відбувається перехід до інформаційного суспільства, знання стають важливим ресурсом соціально-економічного, технологічного й культурного розвитку всіх суб'єктів. Ринок інформації та знань виступає на рівні 3 ринками природних ресурсів, праці і капіталу. В структурі виробництва неухильно зростає питома вага галузей, які забезпечують створення, відтворення та використання інформації. Розвинена інформаційна інфраструктура перетворюється на умову, що визначає конкурентоспроможність території. Це обумовлює актуальність вивчення інтелектуального потенціалу міських громад як чинника підвищення конкурентоспроможності міста.

Дослідженням сутності, змісту, оцінки, формування, нарощування та зміцнення інтелектуального потенціалу займались О. Бобровська [1], С. Вовканич [2], Л. Диба [3], Ю. Драчук, Н. Трушкіна [4], О. Моліна [5] та багато ін.

Мета дослідження: дослідити сутність і складові інтелектуального потенці- 
алу міської громади як чинника їх конкурентоспроможності та визначити шляхи підвищення ефективності формування i відтворення інтелектуального потенціалу міста органами місцевого самоврядування.

Виклад основного матеріалу. Визначимо, що містить поняття інтелектуального потенціалу. Існують різні його трактування. На нашу думку, інтелектуальний потенціал громади - це сукупність знань, компетентності іiі членів, інтелектуальної власності, організаційних можливостей. Особлива увага має бути виділена інтелектуальному потенціалу міст, який містить: людські ресурси - знання, компетентність, творчість членів міської громади; інтелектуальні ресурси - інформацію; інтелектуальну власність - патенти, ліцензії, авторські права, комерційні секрети і торгові марки; структурні ресурси - культуру, організаційні можливості, оргструктури, інформаційні канали міста; бренд-активи - популярність, репутацію, імідж та інші нематеріальні ресурси міста.

Деякі дослідники поширюють поняття інтелектуального потенціалу і на такі фактори, як провідні позиції в галузі використання нових технологій, перманентне підвищення кваліфікації персоналу [6].

Інтелектуальний потенціал відіграє ключову роль в сучасному розвитку міста та розвитку його конкурентних переваг.

У результаті дематеріалізації виробництва і делокалізації інформації, знижується концентрованість економічного простору. Великі міста втрачають свої переваги як центри економічної діяльності [7, с.137]. Якщо основним продуктом стає інформація i вона доступна всюди, тоді виробництво може базуватися де завгодно. У такій ситуації саме інтелектуальний потенціал створює нові конкурентні переваги малим i середнім містам, які отримують можливість стати рівноправними центрами економічної діяльності. Високий інтелектуальний потенціал малих міст у поєднанні 3 низькими витратами на утримання офісу, інфраструктури, витратами на житло, освіту, охорону здоров'я робить їх конкурентоспроможними порівняно 3 великими містами.

Водночас здатність нових технологій скорочувати відстань, час і простір збільшує можливості й ефективність економічної діяльності суб'єктів господарювання, що позитивно впливає на всю економіку малого та середнього міста [8].

Ефективність функціонування підприємств і організацій, що розташовані на території міста, визначається потужністю інтелектуального потенціалу міської громади. Ця ефективність значною мірою визначається тими умовами, які створює місто в сфері інформаційних технологій, різноманіттям інформаційних послуг.

Нинішня економіка грунтується на інформаційних технологіях. Фізична транспортна інфраструктура зараз відходить на другий план. Інформаційні технології створюють нові можливості для розвитку малих i середніх міст. Наявність таких технологій створює переваги для компаній, розташованих на території міста, забезпечує необмежені можливості для новацій, чим збільшує можливості економічного розвитку в містах.

Більшість нових виробництв вимагає кваліфікованих фахівців, тому територія, де $€$ кваліфіковані кадри, має додаткові конкурентні переваги.

Важливою конкурентною перевагою міста мають стати кваліфіковані професійно підготовлені кадри місцевого самоврядування, які володіють сучасними знаннями й сучасними технологіями управління.

На думку В. М. Алексєєва, «не маючи кадрового потенціалу, спроможного врівноважити суб'єкт та об'єкт державного управління за допомогою структур публічного управління, провести реальні реформи досить складно. Тому виховання молодого покоління на нових засадах в управлінні має стати одним із завдань вищої школи, адже досягти кардинальних змін у системі державного управління без спеціалістів такої кваліфікації досить проблематично» [9, c.10]. 
Використання і розвиток інтелектуального потенціалу міських громад, таким чином, стає важливим фактором підвищення конкурентоспроможності малих i середніх міст. Тому пошук конкретних точок більш масштабного розвитку інтелектуального потенціалу повинен стати головним стратегічним напрямом у діяльності органів управління таких міст.

3 огляду на дві складові інтелектуального потенціалу міста, людську й організаційну, можна виділити два основних напрями діяльності адміністрації міста у сфері його підтримки і розвитку: формування та підтримка людського потенціалу міста за допомогою підвищення знань i компетентності громади, підготовки необхідних фахівців; збереження наявного рівня та розвиток сучасних видів інформаційного й організаційного забезпечення всіх споживачів міста. У межах цих напрямів для малого і середнього міста найбільш актуальними стають такі: «керована» міграція кваліфікованих кадрів, пріоритетний розвиток освіти й професійного навчання, розвиток інформаційних технологій, захист інтелектуальної власності, розвиток професійного потенціалу органів місцевого самоврядування. Розглянемо більш докладно перераховані напрями.

Значущим ресурсом розвитку конкурентоспроможності малих та середніх міст $є$ трудові ресурси (наявність, рівень кваліфікації, можливості підготовки кадрів). Одним із конкурентних недоліків більшості малих і середніх міст, як уже зазначалося, $\epsilon$ міграція кваліфікованих фахівців у великі міста, що веде до збіднення інтелектуального потенціалу міста. 3 огляду на те, що розвиток міста залежить значною мірою від кваліфікації працюючих у ньому людей, основними завданнями є наступні: створення та підтримання високого рівня кваліфікації наявних кадрів, утримання кваліфікованих фахівців в місті і залучення для роботи та життя в місті фахівців із інших міст.

Для реалізації поставлених завдань необхідно:

- ефективно використовувати ка- дровий потенціал, виходячи зі стратегії розвитку міста;

- готувати фахівців на перспективу, укладати контракти на підготовку фахівців із провідними вищими навчальними закладами країни та стимулювати повернення молодих фахівців;

- стимулювати повернення своїх кваліфікованих кадрів, які виїхали 3 міста і залучення нових через рекомендації, ексклюзивні контракти;

- підтримувати найбільш талановитих і активних людей.

Слід особливо підкреслити, що процес «керованої міграції» вимагає створення в місті високооплачуваних престижних робочих місць, недорогого, але якісного житла, зручної транспортної інфраструктури, добре розвиненої сфери послуг для населення, упорядкованих зон рекреації, установ якісного медичного обслуговування, дошкільних та освітніх установ, сприятливої екологічної ситуації.

Інвестиціями в інтелектуальний потенціал є створення якісної системи освіти в місті, умов для розвитку інноваційної діяльності.

Освітні та науково-дослідні центри $є$ не тільки джерелом висококваліфікованих кадрів, але й ініціаторами конференцій i семінарів, стимулюють різні інновації, які отримують свій розвиток у конкретних підприємницьких проектах, стають елементом підтримки розвитку бізнесу.

Система освіти повинна бути орієнтована на підготовку кадрів, здатних працювати в сучасних умовах, які швидко змінюються. Для цього необхідно активізувати роботу щодо взаємодії 3 вищими навчальними закладами країни. Особливий акцент в освіті слід ставити на розвитку комунікаційної компетентності - інформатики, іноземних мов, міжкультурного спілкування.

Інший аспект розвитку інтелектуального потенціалу міста - поширення науково-технічних знань.

Одним iз важливих напрямків діяльності освітніх установ $є$ стимулювання науково-дослідницької кооперації освітніх установ міста та господарчих 
суб'єктів, розташованих на його теритоpiï. Місто (за прикладом західних міст) може виступити посередником між сферою науково-дослідної роботи i суб'єктами господарювання через створення інноваційних центрів із передачі нових технологій суб'єктам господарювання, особливо малому та середньому бізнесу. Сучасні інформаційні технологіі створюють нові можливості для розвитку міста і суб'єктів господарювання, розташованих на його території, а також залучають у місто нові виробництва.

Можна виділити наступні напрямки розвитку інформаційних технологій у малих та середніх містах: збереження i розвиток телефонного, мобільного та інтернет-зв'язку; створення i розвиток Інтернет-центрів та інших інформаційних центрів; інформаційне навчання жителів міста і представників господарчих суб'єктів; полегшення доступу до інформації.

Одним із головних завдань є створення відкритого інформаційного простору для всіх споживачів міста (і населення, i господарчих суб'єктів).

Розвинені інформаційні технології створюють широкі можливості для функціонування господарчих суб'єктів (наприклад, електронна комерція, доступ до Інтернет-ресурсів для суб'єктів підприємництва) та нові можливості для міста (Iнтернет-реклама, надання інформаційних послуг і т.п.).

Важливою конкурентною перевагою міста стає інформаційна підтримка малого і середнього бізнесу. Зараз однією 3 найбільш гострих проблем розвитку підприємництва в малих та середніх містах $\epsilon$ недостатність інформаційної підтримки малих підприємств.

Ця проблема може бути вирішена через створення інформаційного центру міста, який забезпечить: доступ до глобальних інформаційних ресурсів, зокрема до Інтернету, набуття навичок отримання інформації в інформаційних системах, можливість бути представленим на індивідуальному веб-сайті і т.п.

Питання відсутності у органів місце- вого самоврядування середніх та малих міст достатніх коштів для розвитку інформаційних технологій може бути вирішене через створення приватно-державних інформаційних центрів.

Захист інтелектуальної власності $\epsilon$ ключовим моментом інтелектуального потенціалу міста і, відповідно, розвитку його конкурентоспроможності. Саме захист інтелектуальної власності дає можливість суб'єктам господарювання отримувати прибуток від інновацій. Стан такого захисту, перш за все патентної системи, може як стимулювати, так і стримувати цю діяльність.

Практичним спрямуванням діяльності місцевої влади може стати створення центру інтелектуальної власності та патентно-ліцензійних послуг. Основним завданням такого центру $\epsilon$ перетворення результатів творчої праці на конкурентоспроможний товар.

Центр створюється для надання підприємствам і організаціям міста та фізичним особам наступних послуг:

- патентно-ліцензійний супровід створення і просування на ринок результатів творчої праці;

- врегулювання взаємовідносин між авторами розробок та їх роботодавцями;

- виявлення ринково цікавих об'єктів інтелектуальної власності;

- забезпечення захисту від несанкціонованого використання об'єктів інтелектуальної власності;

- оцінка ринкової вартості об'єктів інтелектуальної власності.

Глобальні суспільні зміни змінюють не тільки умови господарської діяльності окремих економічних суб'єктів, але й вимоги до керівників, актуалізують питання професійної підготовки посадових осіб місцевого самоврядування.

Розвиток кадрового потенціалу міста базується на наявності висококваліфікованих і професійно підготовлених кадрів, які володіють фундаментальними знаннями в сфері ринкової економіки, публічного управління, правознавства, психології тощо.

Це безпосередньо стосується посадо- 
вих осіб місцевого самоврядування, від компетентності яких залежить ефективність роботи адміністрації міста та ефективність проведених у місті змін.

Професійний потенціал місцевого самоврядування має стати одним із значущих конкурентних переваг міста. Це вимагає систематичного й цілеспрямованого навчання керівних кадрів та відповідальних працівників органів місцевого самоврядування.

Навчання посадових осіб місцевого самоврядування міста $є$ засобом формування професійного потенціалу місцевого самоврядування для подальшого використання цього ресурсу в розвитку конкурентоспроможності міста.

Аналіз складу i професійної підготовки посадових осіб місцевого самоврядування Дніпропетровської області свідчить, що підвищення професійних знань, особливо в умовах децентралізації, потребує більшість керівників і фахівців органів публічної влади.

Важливе значення для державних службовців та посадових осіб місцевого самоврядування малих $\mathrm{i}$ середніх міст мають форма й місце навчання. В основному їх освітні потреби забезпечує Дніпропетровський регіональний інститут державного управління Національної академії державного управління при Президентові України (ДРІДУ НАДУ). Це передбачає тісну співпрацю органів місцевого самоврядування 3 ДРІДУ НАДУ, де можна було б задовольнити всі потреби в підготовці і підвищенні кваліфікації посадових осіб місцевого самоврядування області.

Робота по підвищенню кадрового потенціалу дає відчутні результати: в Дніпропетровській області створена найбільша кількість об'єднаних громад, значна частина державних службовців та посадових осіб місцевого самоврядування отримала диплом магістра. Після закінчення навчання були підготовлені i здійснюються проекти розвитку громад, отримані гранти на розвиток територій, програми підвищення інвестиційної привабливості.
3 досвіду західних компаній, для підвищення рівня професійного потенціалу публічних службовців міста i одночасного вирішення різних завдань, можна порекомендувати створення в містах пізнавально-навчальних співтовариств «спільнот практиків» - тобто груп неформально об'єднаних між собою експертів, які взаємно діляться знаннями. Склад цих груп непостійний, це своєрідний творчий колектив для вирішення певних завдань. Експертами доцільно бути керівникам i фахівцям підприємств та організацій міста, посадовим особам місцевого самоврядування, вченим і науковим працівникам. Цей досвід вже успішно впроваджений протягом останніх років у ДРІДУ НАДУ, зокрема для розвитку професійної компетентності лідерів об'єднаних громад. У квітні-червні 2012 р. Державним фондом сприяння місцевому самоврядуванню в Україні спільно зі Швейцарсько-українським проектом «Підтримка децентралізації в Україні» (DESPRO) реалізовано унікальний експеримент - дистанційне навчання посадових осіб місцевого самоврядування, які планували взяти участь у Всеукраїнському конкурсі проектів та програм розвитку місцевого самоврядування 2012 року [10, с. 9].

В ході роботи таких груп поряд iз вирішенням поставлених завдань відбувається збагачення знаннями публічних службовців.

Важливим питанням $є$ забезпечення відтворення інтелектуального потенціалу громади, зокрема забезпечення наявності відповідних кадрів, здатних управляти процесами розвитку громади. Можна рекомендувати керівникам об'єднаних громад відбирати талановиту молодь i направляти їі для отримання вищої освіти за спеціальністю «Публічне управління та адміністрування» у Дніпропетровський регіональний інститут державного управління Національної академії державного управління при Президентові України за кошти громади, що стане інвестицією успішного управління розвитком громад у майбутньому.

Висновок. Інтелектуальний потенціал 
малих і середніх міст у сучасних умовах стає тією конкурентною перевагою, яка дозволяе їм залучати на свою територію ресурси на рівні 3 великими містами. Тому стратегічним напрямком діяльності місцевої влади має стати найбільш повне використання, збереження та розвиток інтелектуального потенціалу території. Це стосується і людського потенціалу міста - сукупності знань та компетентностей, які мають жителі даного міста, і організаційного потенціалу міста, тобто його технічного, організаційного забезпечення, міських оргструктур, професійного потенціалу адміністраціі.

Основними напрямками діяльності міської влади у сфері розвитку й підтримки інтелектуального потенціалу є: формування та підтримання людського потенці- алу міста, збереження наявного рівня та розвитку сучасних видів інформаційного й організаційного забезпечення всіх споживачів міста.

Основними напрямками розвитку інтелектуального потенціалу малих i ceредніх міст $€$ «керована» міграція кваліфікованих кадрів (збереження наявних $\mathrm{i}$ залучення нових висококваліфікованих фахівців), розвиток інформаційних технологій, захист інтелектуальної власності, полегшення доступу до інформації, пріоритетний розвиток освіти та професійного навчання в місті.

Конкурентними перевагами міста стають не тільки кваліфіковані фахівці, але і професійно підготовлені публічні службовці, здатні сприяти сталому розвитку території.

\section{БІБЛІОГРАФІЧНІ ПОСИЛАННЯ:}

1. Бобровська О. Ю. Інтелектуальні ресурси регіонів і їх використання в умовах децентралізації влади в Україні / О. Ю. Бобровська // Сталий розвиток територій: проблеми та шляхи вирішення: Матеріали VI Міжнародної науково-практичної конференції (м. Дніпропетровськ, 9 жовт. 2015 р.) / за заг. ред. О. Ю. Бобровської. - Дніпро : ДРІДУ НАДУ, 2015. - С. 15-18.

2. Вовканич С. Й. Духовно-інтелектуальний потенціал України та ії національна ідея / С. Й. Вовканич. - Львів : Вид-во ЛБА, 2001. - 540 с.

3. Диба Л. М. Сутність понять інтелектуальний потенціал та інтелектуальний капітал як економічних категорій / Л. М. Диба // Економічний вісник університету. - 2011. - № 17.

4. Драчук Ю. 3. Інтелектуальний потенціал в Україні: проблеми та напрями розвитку / Ю. 3. Драчук, Н. В. Трушкіна // Економічний вісник Донбасу. - 2016. - № 3. - С. 207

5. Моліна О. В. Интеллектуальный потенциал региона / О. В. Моліна // Вісник соціально-економ. дослідж. ОДЕУ. - 2010. - № 40. - С. 365-372.

6. Титова Е. В. К вопросу об инновационном развитии и ценности интеллектуального потенциала / Е. В. Титова // Экономические науки. - 2010. - № 12. - С. 7-12.

7. Ткачук А. Конкурентоспроможність територій : практ. посіб. / А. Ткачук, В. Толкованов, С. Марковський, [та ін.]. - Київ : Легальний статус, 2011. - 252 с.

8. Васильченко Г. Планування розвитку територіальних громад. Навчальний посібник для посадових осіб місцевого самоврядування / Г. Васильченко, I. Парасюк, Н. Єременко / Асоціація міст України - Київ : ТОВ «Підприємство «ВІ ЕН ЕЙ», 2015. - 256 с.

9. Алексєєв В. М. Фахівці для громадівсько-державного управління: суспільний запит і практична підготовка / В. М. Алексєєв // Теорія та практика державної служби: Матеріали науково-практичної конференції (м. Дніпропетровськ, 23 листопада 2015 р.): за заг. ред. С. М. Серьогіна. - Дніпро : ДРІДУ НАДУ, 2015. - С. 10-12.

10. Маматова Т. В. Здобутки та перспективи Е-платформи «Спільнота практиків: інновації у місцевому самоврядуванні» / Т. В. Маматова, С. В. Маліков, О. А. Тертишна, І. Б. Катерняк // Наукові праці (Чорноморського державного університету імені Петра Могили комплексу «Києво-Могилянська академія»). Серія «Державне управління». - 2012. - Т. 194. № 182. C. 9-14. 


\section{REFERENCES:}

1. Bobrovska, O.Yu. (2015). Intelektualni resursy regioniv i yix vykorystannya v umovah decentralizaciyi vlady v Ukrayini [Intellectual resources of regions and their use in conditions of decentralization of power in Ukraine]. O.Yu. Bobrovska (Eds.), Stalyi rozvytok terytorii: problemy ta shliakhy vyrishennia - Sustainable development of territories: problems and solutions: Proceedings of the International Scientific and Practical Conference (pp. 15-18). Dnipro: DRIDU NADU [in Ukrainian].

2. Vovkanych, S.J. (2001). Duhovno-intelektualnyj potencial Ukrayiny ta yiyi nacionalna ideya [Internally-intellectual potential of Ukraine and its national idea]. Lviv: LBA [in Ukrainian].

3. Dyba, L.M. (2011). Sutnist ponyat intelektualnyj potencial ta intelektualnyj kapital yak ekonomichnyh kategorij [The essence of the concepts of intellectual potential and intellectual capital as economic categories]. Economic bulletin of the University, 17 [in Ukrainian].

4. Drachuk, Yu.Z., \& Trushkina, N.V. (2016). Intelektualnyj potencial v Ukrayini: problemy ta napryamy rozvytku [Intellectual Potential in Ukraine: Problems and Directions of Development]. Donbass economic bulletin, 3, 207 [in Ukrainian].

5. Molina, O.V. (2010). Intellektualnyj potencial regiona [Intellectual potential of the region]. Bulletin of the social economy research ODEU, 40, 365-372 [in Russian].

6. Tytova, E.V. (2010). K voprosu ob innovacionnom razvitii i cennosti intellektualnogo potenciala [On the issue of innovative development and the value of intellectual potential]. Economic sciences, 12, 7-12 [in Russian].

7. Tkachuk, A., Tolkovanov, V., \& Markovskyj S. et al. (2011). Konkurentospromozhnist terytorij [Competitiveness of territories]. Kyiv: Legalnyj status [in Ukrainian].

8. Vasylchenko, G., Parasyuk, I., \& Yeremenko N. (2015). Planuvannya rozvytku terytorialnyh gromad [Planning of the development of territorial communities]. Kyiv: TOV «Pidpryiemstvo «VI EN EI» [in Ukrainian].

9. Aleksyeyev, V.M. (2015). Fahivci dlya gromadivsko-derzhavnogo upravlinnya: suspilnyj zapyt i praktychna pidgotovka [Specialists for community and public administration: public request and practical training]. S. M. Serogin (Eds.), Teoriia ta praktyka derzhavnoi sluzhby - The theory and practice of civil service: Proceedings of the International Scientific and Practical Conference (pp. 10-12). Dnipro: DRIDU NADU [in Ukrainian].

10. Mamatova, T.V., Malikov, S.V., Tertyshna, O.A., \& Katernyak I.B. (2012). Zdobutky ta perspektyvy E-platformy «Spilnota praktykiv: innovaciyi u miscevomu samovryaduvanni» [Achievements and Prospects of the E-Platform «Community of Practitioners: Innovations in Local Self-Governance»]. Scientific works (The Black Sea State University named after Petro Mohyla of the Kyiv-Mohyla Academy Complex»). Governance, 194 (182), 9-14 [in Ukrainian].

Липовська Катерина Олександрівна - аспірант

Дніпропетровський регіональний інститут державного управління Національной академії державного управління при Президентові Украӥни

Адреса: 49044, м. Дніпро, вул. Гоголя, 29

Email: katebass777@gmail.com

Botvinov Rostyslav G. - Post-Graduate Student

Dnipropetrovsk Regional Institute of Public Administration, National Academy of Public Administration under the President of Ukraine

Address: 29 Gogol, str. Dnipro, 49044, Ukraine

Email:katebass777@gmail.com 